\title{
AN APPRAISAL OF THE PRESENT TREATMENT OF BARBITURATE POISONING ${ }^{1}$
}

Leonard Cecil Jenkins, B.A, IM.D, C.M, and Horace B. Graves, B.A., M.D., C.M ${ }^{2}$

\section{The Importance of Barbiturate Poisoning as a Therapeutic Problem}

The greatly increased importance of acute barbiturate poisoning as a therapeutic problem is forcefully documented (1) by recent statistics from Britain $(2,3)$, the Scandinavian countries $(4,5)$, and the United States $(6,7)$. The annucl consumption of barbiturates in the United States is 300 tons. The increasing popu_arity of barbiturates as suicidal agents has created a world-wide problem The incidence of suicide by means of barbiturates is approxirnately 5 per cent of that for all poisons and in large cities this figure may be fourfold. About 20 per cent of hospital admissions for acute drug intoxication are cases of barbiturate poisoning; only carbon monoxide porsoning exceeds this figure. About 1,500 deaths from acute barbiturate intoxıcation occur annually in the United States alone When one takes into account the discrepancy between reported and actual number of deaths, as well as the probable ratio of 13 to 1 of reported non-fatal cases to fatal cases, some perspective is gained in assessing the magnitude of the problem

\section{A Summary of the Pathologic Physiology of Acute Barbiturate PoIsONIng}

\section{Definition of Babiturate Poisoning}

Barbiturate poisoning refers to the physiological and psychological changes produced by a toxic amount of any member of this class of drugs $(6,7)$

Moderately severe poisoning usually occurs when an amount of barbiturate has been ingested which is five to ten tumes the full oral hypnotic dose The fatal dose varies with many factors, as will be noted later, and cannot be stated with certanty, but when over fifteen to twenty times the ordinary hypnotic dose has been absorbed, severe poisoning will ensue (7) and even expert therapy may fail to save the patient's life.

\section{Aetiological Factors in Acute Barbiturate Poisoning}

There are three main factors. Poisoning by barbiturate may occur in three ways (1) Accidentally, in the course of its therapeutic use, when given intravenously for anaesthesia by persons not sufficiently experienced in this field, and rarely 1diosyncrasy may be the basis of intoxication. (ii) Suicidal intent has its modes and the use of barbiturates is currently in vogue. There is usually some psychiatric disorder, most commonly in the reactive depressions, manic-depres-

\footnotetext{
1Presented at the Annual Meeting of the Canadian Anaesthetists' Society, Saskatoon, Saskatchewan, June 24-26, 1957.

2Department of Anesthesiology, Vancouver General Hospital, and University of Britısh Columbia, Vancouver, B C
} 
sives and schizophrenics. (iii) Occasionally, acute barbiturate poisoning may be due to what has been called "automatism." For example, failure of the drug to produce sleep may cause a confusional state in which the patient does not remember having already taken medication and he may then unwittingly ingest an overdose (6).

\section{Toxicological Factors in Acute Barbiturate Poisoning}

(a) Central nervous system. The major action of the barbiturates is depression of the central nervous system. The intensity of this effect depends upon (i) the particular barbiturate ingested, which will govern its subsequent in vivo metapolism, distribution and excretion; (ii) the dose; (iii) the clinical status of the patient, such as age, sex, werght, and reflex irntability; (iv) environmental factors (8), such as temperature, barometric pressure and humidity. Evidence seems to indicate that the barbiturates act at all segmental levels and at all levels of functional organization of the central nervous system. Although the finer mechanism of action is not yet fully elucidated, nevertheless two properties of barbiturates have been established beyond question $(9,10)$. There is an elevation of the threshold of stimulation of neurons by stabilization of the cell membrane (9) and prolongation of the time for recovery from excitation. The neurons of the cerebral cortex, the reticular activating systems of the mid-brain and diencephalon are most susceptible to depression by the barbiturates (10). Internuncial neurons are more susceptible than neurons which directly subserve reflex arcs. The cerebellar, vestrbular and spinal systems are less sensitive and the vital medullary systems concerned with respiration and circulation are least sensitive. Thus, barbiturates first depress the cells of the reticular activating system and the cerebral cortex. These actions lead to difficulty in thinking, impairment of judgment and finally to sleep. As the degree of intoxication increases, the activity of the cortical and reticular cells is further depressed, the cerebellar and vestıbular systems become involved, and depression of spinal cord activity appears. The results are increasing imparrment in mental ability, confusion, light coma, ataxia, and depression of deep tendon reflexes. As the intoxication deepens, coma becomes complete and the deep reflexes are lost (6).

(b) Cardio-vascular system There is a central depression of the vasomotor centre with peripheral vasodilatation and hypotension. Barbiturates can also produce dilatation of the finer blood vessels by directly affecting their musculature. Excessive concentrations may dilate and injure capillary beds so that shock may ensue. The untoward effects on the cardiovascular system observed in acute barbiturate poisoning are to some extent secondary to hypoxia due to respiratory depression. However, experimentally, very large doses have been shown to produce cardiac irregularities and even cardiac failure in heart-lung preparations.

(c) Respiration The medullary respiratory centre is depressed directly, breathing becoming slow and shallow. This is the major danger in acute barbiturate intoxication. Indeed, death from barbiturate poisoning may be due to respiratory failure, but not necessarily so In barbiturate poisoning, the sens1tivity of the respiratory centre to the normal carbon dioxide stimulus may be abolished, but the intensity of the reflex response to hypoxic chemo-receptive 
impulses may not be greatly affected. Thus breathing, may be largely controlled by the hypoxic drive to respiration through the carotic and aortic c_lemo-receptor mechanism. Reduced oxygen tensions in the blood may thus temporarily mask serious medullary depression by barbiturates. Very low oxygen tensions ultimately exert a depressant effect on the medulla, combining with barbiturate depression to cause death. This fact is important since administration of oxygen alone at this stage may remove the stimulus to respiration and cause cessation of breathing.

\section{Clinical Aspects of Acute Barbiturate Poisoning}

(a) Signs and symptoms. It will be understood from the foregoing discussion, that the signs and symptoms are referable especially to the central nervous, cardiovascular, and respiratory systems. They vary with the amount and type of drug used, the length of time since it was ingested, and duration of time without treatment. In general (6), the larger the dose the more rapidly signs and symptoms appear and the longer they persist, regardless of the drug used. Pentobarbital and secobarbital proc uce coma quickly but recovery is re_atively rapid Barbital and phenobarbital slowly induce coma which is prolonged. These differences are due to variations in the speed of the detoxification of the different barbiturates. Cases of acute barbiturate intoxication may be classified as mild, moderate or severe, according to the degree. of depression of the central nervous system. Differentiation of these various grades is very important in planning treatment and assessing the results $(11,12)$.

(i) Mild intoxication. The patient is not comatose and is easily aroused by mild stimulation. There is impairment of mental ability, judgment and emotional stability. Neurological signs include transient nystagmus on lateral gaze, dysarthria, ataxia in gait and station, adiodokokinesis, and depression of the superficial skin reflexes.

(ii) Moderate intoxication. The patient is comatose but can be aroused by very vigorous manual stimulation or by the intravenous injection of $5 \mathrm{ml}$. of a 10 per cent solution' of metrazol. Respiration is slow but not shallow, and cyanosis is not present. Nystagmus is constant. The patient when awakened cannot stand or walk alone because of ataxia. The deep tendon, corneal, and gag reflexes are depressed but not absent. Patients with mild or moderate barbiturate poisoning almost always recover.

(iii) Severe barbiturate intoxication. The patient is comatose and cannot be aroused by manual stimulation or by metrazol (11). Respiration is slow, shallow, and cyanosis is frequently observed. There is often Cheyne-Stokes rhythm and pulmonary oedema may be present. The deep tendon reflexes are markedly depressed and may be unobtainable. A Babinski response is often elicited. Corneal and gag reflexes may be absent. The pupils may be constricted and unreactive to lig it; if anoxia is severe, they may be dilated. The pulse is rapid and thready. The blood pressure may fall to shock levels. Unless the patient has developed bronchopneumonia, the body temperature is $0.5^{\circ}$ to $2.0^{\circ} \mathrm{C}$. below normal. Urine formation is decreased or suppressed. This fact is of therapeutic importance because the longer-acting barbiturates cannot be adequately detoxified in the tissues and recovery from their effects is dependent upon adequate renal function. 
(b) Diagnosis. The diagnosis is made from a careful evaluation of a history, from friends, relatives and police officers, the physical findungs and by identifying barbiturate (13) in stomach contents, blood or urme. Of course, acute barbiturate poisoning must be differentrated from all other conditions which cause coma: for example, head injuries, cerebıo-vascular accidents, brain túmours, meningitıs, encephalits, drabetic and uraemic coma, syncope due to cardiovascular causes, hepatic coma and coma due to other intoxicants, alcohol, morphine, bromide and other aliphatic hypnotics

(c) Assessment of seventy, progress of intoxication and response to treatment is best made by keepmg an accurate chart of the status of the important vital functions and reflexes every 15 to 30 minutes. By following such a chart, one can quickly detect the deceptive simulation of deep barbiturate coma by the secondary effects of hypoxia, simple correction of hypoxia rapidly leads to $1 \mathrm{~m}$ provement in vital signs

(d) Complications The most common complications of acute barbiturate intoxication are pulmonary (6) Death, if it occurs, is usually the result of paralysis of the respiratory centre. The shorter-acting barbiturates are particularly liable to produce death from respiratory depression (7) If death is delayed, vasomotor collapse, cerebral oedema and hypostatic pneumonia are the usual causes. Bronchopneumona, lung abscess, or other pulmonary complication may occur in a patient who has regamed consciousness and apparently recovered Hyperthermia and lower nephron nephrosis are also serious complications Decubitus ulcers may develop (6). It is not unusual for acute barbiturate intoxication to be superimposed on barbiturate addiction, and if this is true, severe withdrawal signs may appear, after the patient has recovered from coma.

There are no characterıstic autopsy findings, although diffuse, non-specific cerebral lesions may occur (7)

(e) Prognosis depends on the amount of drug taken, the particular barbiturate used, the general health of the individual, the interval elapsing between the ungestion of the poison and the beginning of treatment and the nature of the therapy

Apparently, hyperaemia of the gastric mucosa caused by a strongly alkaline sodium barbiturate facilitates direct and rapıd absorption from the stomach. The onset of coma is so rapid that barbiturate intoxication is often not suspected by the physician (6)

\section{Thfrapeutic Management of Acute Barbiturate Poisoning}

The objectives of therapy are: (1) to prevent in so far as possible fut thes absorption from the intestine, (ii) to support the respiration and blood pressure, (iii) to decrease the intensity of depression, and (iv) to prevent complications

There is a general tendency to over-treat the patient poisoned by central depressants In cases of mild to moderate intoxication, little therapy other than supportive measures may be requured The patient may be better off if allowed to recover unaided by strong analeptics than if he is the recipient of well-intentioned but lll-designed treatment $(4,5,7)$. 


\section{Supportive and Expectant Therapy}

This approach to the management of acute barbiturate possoning is advocated by all groups and particularly by Clemmesen (5) and Nilsson (4). The importance of (1) adequate oxygenation, and (ii) respiratory exchange (endotracheal intubation indicated if pharyngeal and larygeal reflexes absent), (iii) toilet of the pharyngobronchial tree, and (iv) use of pressor agents for vascular hypotension and wide spectrum antibiotics, cannot be stressed too heavily, as the basis of any therapeutic programme Using these principles in the management of acute barbiturate poisoning the results of Clemmesen's group (5) in Denmark are indeed impressive. Over the past six years they have reduced the mortality rate from barbiturate poisoning in Denmark from 25 per cent to 37 per cent and even down to 16 per cent in Copenhagen, despite an increase in the number of cases admitted to Danısh hospitals, which have more than doubled over this period.

\section{Chemical Antidotes}

(a) Central analeptic drugs Present-day therapeutic controversy, in the management of acute barbiturate poisoning, centres about the use of analeptic drugs, particularly picrotoxin and pentylenetetrazol (metrazol). The range of published opinion mcludes enthusiasm (12, 14), cautious acceptance (15); ambivalence (16), and condemnation $(4,5)$

The analeptic drugs have been used to stimulate the depressed respiratory centre and lessen the degree of central depression by excitation of higher centres. Caffeine and sodium benzoate, and Nikethamide (coramine) have been used, but their value is questionable (17). The use of strychnne has fallen from favour (7). Sympathomimetic amines with a relatively strong central stimulant action and weak peripheral sympathetic effect have been employed. That is, amphetamine (benzedrine), d-amphetamine (dexedrine), and desoxyphedrine (methedrine) are viewed by some as the agents of choice (7). Others prefer metrozol or picrotoxin $(12,14)$. Combinations of analeptics are often of more value than a single agent, and such combinations as picrotoxin and amphetamine and picrotoxin and metrazol $(6)$ have been used

In the evaluation of individual analeptic agents Eckenhoff (15) points out that three facts must be recognized: (i) patients have recovered from more than the usual fatal dose of barbiturate without aid of analeptics; (ii) definite hazards exist in the use of analeptics, (iii) no analeptic, as yet, can be depended on to cause the recovery of a patient deeply depressed from a usually fatal dose of a barbiturate. Further, it is difficult to obtain significant data owing to (i) a wide variability in human and animal response to barbiturate; (ii) great variety of M.L.D.; (iii) different degrees of absorption; (iv) presence of co-existent disease; (v) age; (vi) physical state; (vii) great variability in the period between treatment. Nevertheless, each central stimulant has its ardent advocates who present clinical data purporting to show the superiority of their particular analeptic, but unfortunately often fail to clearly indicate the variables involved in their series.

The case against analeptics has been forcefully presented by Nilsson (4) and 
Clemmesen (5). Nilsson treated 176 cases by conservative (supportive expectant) measures alone, with a fatality rate of only 1.7 per cent, even in the group of 87 severely poisoned patients the death rate was only 3.45 per cent. These results are better than those in most reports of adequately large series of cases treated with analeptics.

The case for analeptic therapy is well campioned by Kappanyi and Fazekas $(11,12)$, who regret Nilsson's pharmacotherapeutic nihilism, admit that not all patients require central stimulant therapy, but emphasize the value of analeptics in properly selected cases. They propose that differentiation can be made between those not requiring analeptics and those requiring vigorous therapy with picrotoxm and metrazol by the results of the intravenous injection of an orientation dose, $5 \mathrm{ml}$. of a 10 per cent metrazol solution. If twiiching and grimacing occur and the corneal and deep tendon reflexes return, only symptomatic care is indicated and analeptics need not be used.

The action of metrazol is prompt and brief, so that the effects are more readily controlled than those of pictrotoxin which are sometumes delayed for as long as ten minutes, even after intravenous injection, a fact which complicates its clincal use.

Since picrotoxin was first introduced for the therapy of acute barbiturate poisoning by Arnett (18) in 1933, there have been numerous reports of dramatic and life-saving results from its use. When proserly administered, picrotoxin is unequaled for its long-sustained stimulatory efects. By acting on the medulla and brain-stem, it improves respiration and circulation, hastens the return of swallowing and cough reflexes, and induces restlessness and movement which prevent dangerous crrculatory stasis. Metrazol though more transitory in its action than picrotoxin is more effective on higher cerebral centres

The dose and route of administration of picrotoxun depend upon the urgency of the case. In seriously poisoned patients in coma, the drug is given intravenously by one of two methods. Method I: a continuous infusion at the rate of 1 or $2 \mathrm{mg}$./min. until the corneal and swallowing reflexes appear or until very slight twitchings of the facial muscles or extremities occur; then give intramuscularly in doses of 3 to $6 \mathrm{mg}$. every 15 to 30 minutes depending on the course of recovery and response. Method II: fractional method by which 6 to $12 \mathrm{mg}$. (2 to $4 \mathrm{ml}$. 0.3 per cent solution), are given intravenously every 10 to 20 minutes

There are serious dangers with picrotoxin that should be realized. Because it has a long latent time of action, an injection of picrotoxin should not be repeated until the previous dose has manifested its full effect, which may require ten to twenty minutes or longer. Complications with picrotoxin arise from the fact that if the clinician does not wait this full interval (which unfortunately is so often the case), convulsions are most likely to ensue. This leads to secondary depression of a postictal type and from the subsequent barbiturate which is administered to control the convulsions. Thus a vicious circle is begun.

The administration of these potent analeptic drugs necessitates careful and close observation of the patient, and good judgment in the selection of doses and intervals between doses.

If metrazol is employed, it is given intravenously in amounts of 3 to $5 \mathrm{ml}$. of a 10 per cent solution every 5 min. for 2 or 3 doses, as required. 
The objective in analeptic therapy is to restore and continuously maintain active reflexes, spontaneous involuntary movement, and responsiveness to pain, until sufficient barbiturate is eliminated to ensure recovery and yet not produce convulsive twitchings from an overdose. One does not attempt to restore the patients to full consciousness by drug therapy. Indeed, this is an impossibility and convulsions will occur if such an attempt is made.

(b) Sodium succinate and related compounds. From experiments based on the observation made by Quastel and Wheatley (19) that barbiturates inhibit the utilization of glucose, lactate and pyruvate but not of succinate by brain tissue in vitro, Soskin and Taubenhaus (20) reported that succinate was an effective antidote against pentobarbital. This report initiated a number of investigations in animals (21-27), and in man to determine whether certain dicarboxylic acids (succinic, fumaric, malonic (28), pyruvic (25)) could shorten the duration or decrease the intensity of barbiturate depression. Although the use of disodium succinate has its advocates, they are few (27), the consensus being that this approach to antidotal therapy has not as yet yielded acceptable evidence of benefit.

Because of the fallure of succinate and of the dangerous reactions accompanying overdosage with central analeptics there have been a continuing constant search for a chemical antidote which might effectively, without producing convulsıons, reverse barbiturate depression by specific antagonism. Along this line, recent compounds introduced are those mentioned below.

(c) B-B-ethyl methyl glutarimide (Megimide; NP 1 ; Bemeg.ide) and 2-4diamino-5-phenylthiazole (D.A.P.T.). (i) History. B-B-ethyl metayl glutarimide was first synthesized in 1911. Shaw first observed its anti-barbiturate activity in 1951 and subsequently investigated it in animals (29) and in man (30) in 1955.

(ii) Chemistry and pharmacology: Megimide. Marshall et al. (31) point out that there is a similarity between part of the structure of Megimide and barbiturates, the grouping

being common to both.<smiles>[R]C([R])C(=O)N[R]C=O</smiles>

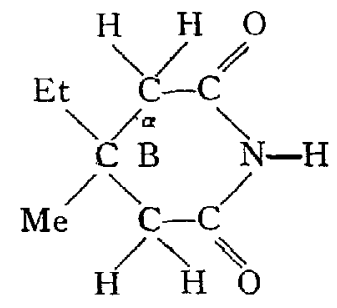

B-B-ETHYL METHYL GLUTARIMIDE (MEGIMIDE)

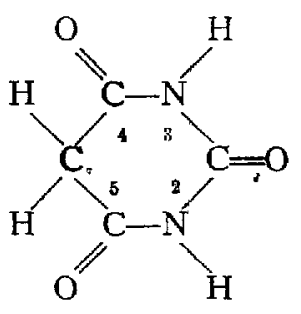

BARBITURIC ACID

Because of this the hysothesis was advanced that probably the similarity of structure enables the g-utarimide, when offered in sufficient concentration, to displace the barbiturate molecules from the receptors to which they are attached and so to reduce their effect, that is, competitive inhibition. Megimide is more 
active than D.A.P.T. Recently, Cass (32) studied electro-encephalographic patterns of the analeptic action of B-B-ethyl methyl glutarımide in rabbits against pentobarbitone, thiopentone, amylobarbitone, Thialbarbitone and other hypnotics such as chlorolon, ether and oblivon. Megimide reversed the EEG changes induced by pentobarbitone, thiopentone, amylobarbitone and Thialbarbitone, but produced only minimal improvement, if any, in anımals depressed by nonbarbiturate hypnotics (chlorolon, ether, oblivon). In the basis of EEG patterns Megimide was found to be a more effective barbiturate antagonist than coramine, methedrine, picrotoxin and leptozol.

Although the biophysical processes resulting in the electrical changes shown in these EEG's are not fully known, the assumption is made that a drug which restores an electrical pattern similar to that of light anaesthesia is antagonizing the anaesthetic used Evidence does not suggest any particular type of antagonism although Megimide only antagonizes barbiturates Regardless of its mode of action, as a stimulant it has novel features. It does not raise the blood pressure or induce hyperpyrexia as do analeptics, and it does not seem to provoke increased oxygen consumption by the cerebral tissue

Because it may cause convulsions in large doses, Shulman et al (30) proposed a second substance DAP.T (2-4-diamino-5-phenylthiazole) be used in conjunction with it It is itself a weak barbiturate antagonist, a good synergist to $\mathrm{NP}_{13}$ as well as an excellent respiratory stımulant $(30,33)$

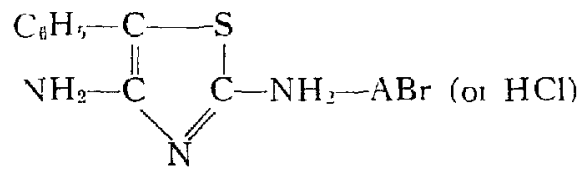

It is claumed to greatly reduce the risk of toxic manfestations which sometimes occur when $\mathrm{NP}_{13}$ alone is given rapidly and in high dosage.

Shaw et al (29) have indicated that both these substances possess a high therapeutic index

(111) Advantages clamed. Because of favourable results in recent clinical trals $(29,30,33,34,35)$, showing restoration of the patient from a deep coma to a desired state of light anaesthesia-"the safe state"-from which spontaneous recovery to full consciousness usually occurs within eight hours, it thus removes the need for strict, prolonged medical and nursing care, and virtually elıminates the risk of complications, and will eventually further reduce the death rate

(1v) Mode of administration. Have 2.5 per cent thiopentone $\mathrm{Na}$ at hand Give intravenously every 3 to $5 \mathrm{~min} .1 \mathrm{ml}$ of a solution with $15 \mathrm{mg}$. of amiphenozole followed at once by $10 \mathrm{ml}$. of a solution with $50 \mathrm{mg}$. of Megumide. This is continued until the patient is restored to what is called the "safe state," that is, when pharyngeal, laryngeal reflexes return, blood pressure, heart rate and respiration approach normal Usually two hours of treatment in a deeply comatose patient is adequate On an average $1 \mathrm{gm}$. of Megimide and $0.3 \mathrm{gm}$. of D.A.P.T., is required, though the amounts may vary with the depth of the intoxication.

(v) Complications. Vomiting or retching are usually the earliest and may be the only clinical signs of incipient toxicity This may be followed by slight 
flickerıng of the fingers and is readily reversed by small amounts of intravenous 2.5 per cent thiopentone (30). Regression may occur and further small treatments are indicated. This is more likely to occur when coma has been of long duration before therapy began, or if a long-acting barbiturate is involved. Lauw and Sonne (35) have observed mild, short-lived attacks of tonc-clonic convulsions. Psychic disturbances have been reported recently following Megimide therapy $(35,36)$. They occurred mainly in addicts to barbiturates, but also in non-addicts

(vi) Present status. Megimide and D A P T have a strikang stimulating effect on reflex activity as well as on respiration, and they are valuable for bringing patients into a stabilized physiological state, the so-called "safe state" (35) On the other hand, in several recent series of clnical experiences (33-37) it was found that in severe cases the drug did not influence the rate at which barbituric acid was eliminated, the blood level of barbituric acid on waking, or the duration of coma. The majority of workers do not support the hypothesis that Megimide is an antagonist in a strictly biochemical sense (like, for example, nalorphine in morphine porsoning). It seems that the drug counteracts barbiturie acid by a central stimulant action. This is indicated by the reflex hyperactivity, the EEG changes, and the complications caused by an overdose, which are not readily compatible with the assumption of a simple biochemical antagonistic effect, as, for example, competitive inhibition. Most feel that if only because of their effect on respiratory paralysis they are valuable adjuvants in the treatment of acute barbituric acid poisoning (33).

\section{Removal of the Barbiturate from the Body}

Unfortúnately, none of these previously mentioned measures may be sufficient in the severely poisoned patient and in the absence of a well-established chemical antidote The most direct approach to the management of acute barbiturate poisoning is the removal of the drug from the body. Several ways of effecting this were tried

(i) Gastric lavage, (ii) induction of diuresis These methods are limited $\mathrm{m}$ efficacy and carry potentral dangers. Patients are frequently seen too late for effective lavage and it is a procedure which markedly increases the danger of aspiration. The value of diuresis is limited by the metabolic and renal excretion patterns of most barbiturates, particularly the short-acting ones.

(iii) Peritoneal lavage is not successful in dogs in shortening recovery period (41).

(iv) Haemodialysis. In the past three years, considerable experımental $(38,39$, 42 ) and clinical data $(1,39,40,43)$ have accumulated on haemodialysis as an efficient method of barbiturate removal. Barbiturate molecules can be mobilized from tissue and made to pass into the blood stream and then through a cellophane membrane into a dialyzing solution.

An excellent recent report by Berman (1) of eight cases of severe barbiturate poisoning treated successfully by haemodialysis, the largest series of patients treated in this manner to date, is of some significance. One of these patients, a 28-year-old, 83-1b epileptic. is of particular interest. She had ingested $25 \mathrm{gm}$ of 
phenobarbital, and did not respond to metrazol, picrotoxin, caffeine or sodium benzoate therapy. When seen by Berman's group 49 hours after ingestion of the drug, she was comatose, areflexic. Her mitial blood barbiturate level was $25.3 \mathrm{mg} . / 100 \mathrm{ml}$.

After three dialyses, $9.33 \mathrm{gm}$. of phenobarbital were recovered, representing 37 per cent of the ingested dose, a figure in good agreement with the experimental dialysis of phenobarbital (38). This indirectly corroborated the patient's statement concerning the amount of drug ingested, a statement otherwise difficult to believe. Following the dialyses return to consciousness was rapid and complete.

The efficiency of haemodialysis in removing barbiturate varies directly with the concentration gradient from blood to bath; therefore, the higher the blood level of barbiturate, the faster its removal by haemodialysis will be. Also, the amount of drug which can be removed increases with the severity of poisoning, a unique feature for any therapeutic procedure.

Other variables are the surface area of the cellophane which is relatively constant, but flow rates through the machine are influenced by cannula size, cardiac output, mean arterial pressure, all of which are difficult to maintain at maximally efficient conditions. In practice this means that patients who are initially in poor condition and who improve as dialysis proceeds, simultaneously improve the rate of extraction of barbiturate from their blood and tissues. Thus dialysis improves both the patient's condition and its own efficiency as the treatment proceeds. It has been indicated (44) that the dialysis technique is complex, requiring highly trained personnel, close supervision and is not without hazards of its own. However, results such as Berman's (1) suggest that it may come to have an important place in the treatment of severe barbiturate poisoning.

\section{Physical Method of Stimulation}

Electro-stimulation (non-convulsive). Robie (45) has claimed that non-convulsive electro-stimulation (of temporal areas) lessens barbiturate depression and favourably influences respiration. He advocated the use of unidirectional electro-cerebral stimulation. A modulated current of 5 to 7 milliamperes is applied through electrodes fastened to the temples. According to Robie, the application of the current immediately increases the depth of respiration, and the effect on respiration can be varied by altering the modulation and amount of the current. Duration of stimulation is usually $11 / 2$ to 5 hours, whereupon the patient can be awakened. The mechanism of the response had been explained as a result of the activation of cortical or diencephalic structures. However, this does not appear to be altogether true since Blackly (46) was able to get similar respiratory responses when the electrodes were applied peripherally (on the medial aspect of middle part of each lower leg). Thus it is now believed that respiratory augmentation resulting from electro-stimulation is a reflex mechanism dependent on the excitation of general somatic afferent nerve fibres. Blackly feels that peripheral stimulation is preferable to bitemporal, since respiratory inhibition which sometimes occurs with bitemporal stimulation is less likely to occur in the peripheral method. He failed to indicate that stimulated dogs awakened earlier 
than control anumals. This method of management requires further confirmation from experiments on human beings.

\section{Comments and Conclusions}

(a) The science of human toxicology is continually beset by problems relating to minumum lethal doses, fatal blood levels of drugs, and effectiveness of treatment, inasmuch as there can never be a sizable body of data wherein the pertinent variables are well controlled. For example, in a clinical series of patients with acute barbiturate poisoning, factors such as inaccurate history of dosage, ratio of ingested dose to absorbed dose, time elapsed before treatment, underlying physical state (for example, renal function, visceral pathological changes in the kidney and liver), and individual variation in tolerance to drug may make it difficult to assert that any given patient would have survived with or without a particular therapeutic procedure.

(b) The world-wide prominence of acute barbiturate poisoning is a stimulus for continuing improvements in therapy.

(c) A compre.ensive understanding of the pathological physiology of acute barbiturate poisoning is an essential prerequisite to intelligent therapy.

(d) The initial assessment of severity, progress of intoxication and response to therapy are all important guides in the choice of subsequent management of patients with acute barbiturate poisoning.

(e) All groups agree as to the benefits and helpfulness of supportive expectant therapy. The present-day controversy centres on the use of central analeptics of which picrotoxin and metrazol are most commonly employed either separately or conjointly. Their use is not without dangers. They are not always effective in severe barbiturate poisoning.

( $f$ ) The consensus of opinion is that sodium succinate is not useful in acute barbiturate poisoning.

(g) Recently, non-convulsive electro-stimulation has been advocated, but it has yet to be confirmed in human patients as being beneficial in acute barbiturate poisoning.

(h) Two major recent advances in the treatment of acute barbiturate poisoning are: (i) the use of Megimide and D.A.P.T. as chemical antidotes. Initially, they were believed to be true chemical antagonists to barbiturates on the basis of their structural similarity. However, it now appears that they are central analeptics but with a high specificity to barbiturates. They are by no means ideal since toxicity occurs in overdosage.

(ii) Haemodialysis, a very rational approach to the treatment of acute barbiturate poisoning, has shown very encouraging clinical results in the treatment of severe barbiturate poisoning. Unfortunately it is a rather complex technique as it exists today.

\section{RÉSUMÉ}

La fréquence fortement croissante des empoisonnements aux barbituriques pose un problème thérapeutique dont la documentation est abondante d'après 
les statistıques faites en Grande-Bretagne, dans les pays scandinaves et aux EtatsUnis. Aujourd'hui, ces médıcaments sont devenus la proncipale cause de l'intoxicaton médicamenteuse argue dans le monde.

Cette expansion universelle des empoisonnements aigus par les barbituriques est devenue un stimulant pour essayer d'améliorer les traitements à prescrire.

Pour instituer une thérapeutıque intelligente, ll est essentiel de connaître au préalable la physiopathologie de l'empossonnement aigu aux barbituriques. Le tableau clinique initial de la gravité de l'intoxication, de son aggravation et de la réponse du malade à la thérapeutique sont des facteurs importants pour aider à faire le choix des traitements ultérieurs dans l'empoisonnement aigu par les barbituriques.

Les objectifs de cette thérapeutıque sont: $(a)$ prévenir, autant que possible, une absorption plus consıdérable du médicament par l'intestin; $(b)$ maintenır les échanges respiratorres et la tension artérielle; $(c)$ corriger la dépression; (d) prévenir les complications.

Il existe une tendance générale à donner trop de médicaments au malade empoisonné par des dépresseurs centraux Dans les cas d'intoxication légère et modérée, il peut y avorr peu à farre à part les mesures stimulantes. Le malade pourra peut-être en sortur meux sı on le lassse revenir seul sans administrer d'analeptiques puissants que si l'on institue un trattement bien intentionné mass susceptible de le rendre malade

Tous sont d'accord sur les bienfaits et l'utilité de la thérapeutıque de support, soit: une oxygénation adéquate et des échanges respuratorres convenables (intubation endotrachéale si les réflexes pharyngés et laryngés sont absents) la vidange de l'arbre pharyngobronchique, l'emplor de vasopresseurs pour corriger l'hypotension et des antıbiotıques à puissance étendue.

Aujourd'hui, la controverse réside dans l'emploi des analeptaques centraux dont la picrotoxine et le metrazol sont les plus fréquémment employés soit ensemble, soit séparément On ne les emploie pas sans danger. Ils ne sont pas toujours efficaces dans l'empoisonnement avec les barbituriques

Tous sont d'accord pour affirmer que le succinate de sodium n'est pas utile dans ces cas.

On a préconisé, récemment, une électrostımulation non convulsivante mais il n'est pas confirmé que, chez l'humain, elle serait utile dans l'nntoxıcation aigue par les barbituriques.

Les deux principales acquisitıons récentes dans le traitement de ces intoxications aigues sont:

(a) L'emploi du Megimide (B-B-ethyl methyl glutarimide) et du D A.P.T. (2-4-dıamino-5-phenylthrazole) comme antidotes chimiques. Au début, on croyait qu'ils avarent un réel pouvorr chmıque antagoniste aux barbituriques en se basant sur leur similarité de structure. Toutefois, maintenant, ll semble bien qu'ils sont des analeptiques centraux mais possédant une haute spécificité pour les barbituriques. De toute façon, lls ne constatuent pas le traitement idéal puisque leur surdosage devient toxique

(b) L'hémodialyse qui semble un abord très rationnel de l'intoxication aiguë par les barbituriques a donné des résultats cliniques très encourageants dans 
ces cas. Malheureusement, telle qu'elle se pratique aujourd'hui, elle requiert une technique complexe.

\section{REFERENCES}

1. Berman, L B, Jeghers, H J., Schreiner, G. E., \& Polotta, A. J. Hemodialysis: An Effective Therapy for Acute Barbiturate Poisoning. J.A.M A. 161: 82 (June 30, 1956).

2. Foreign Letters (England): Growing Rusks from Barbiturates J.A.M.A. 156: 735 (Oct. 16, 1954).

3. Shulman, A., Shaw, F. H., Gass, N M., \& Whyte, H. M New Treatment of Barbiturate Intoxication Brit. M.J 1. 1238 (May 21, 1955).

4 Nirsson, E On Treatment of Barbiturate Poisoning. A Modified Clinical Aspect Acta. Med. Scandinav. 139, suppl 253 (1951).

5. Clemmesen, C. New Line of Treatment in Barbiturate Poisoning Acta Med Scandinav. 148. 83 (I954).

6. IsBell, H. Acute and Chronic Barbiturate Intoxication. Veteran's Administration Tech Bull TB 10-76 (1951).

7. Goonman, L. S., \& Gilman, A. The Fharmacological Basis of Therapeutçs. A Textbook of Pharmacology, Toxıcology, and Therapeutics for Physıcians and Medical Students New York. Macmillan (1955).

8 Richards, R. K., \& TAYLoR, J D Some Factors Influencing Distribution, Metabolism, and Action of Barbiturates. A Review Anesthesiology 17 414-458 (May, 1956)

9 Eccles, J C. Synaptic Potentrals of Motorneurons J Neurophysiol. 987 (1946).

10 Wickler, A Sites and Mechanisms of Action of Morphine and Related Drugs in the C N.S Pharmacol. Rev 2: 435 (1950)

11 Kappanyi, T., \& FazeKas, J F Acute Barbiturate Poisening Analysis and Evaluation of Current Therapy. Am J.M Sic 220 559-576 (1950)

12 Kappanyi, T., \& Fazeras, J. F Pharmaceutical Nihilism in the Treatment of Acute Barbiturate Poisoning. Am J. M Sc. 224 577-585 (1952)

13 Wright; J. T. The Value of Barbiturate Estmations in the Diagnosis and Treatment of Barbiturate Intoxication. Quart J Med 24. 95-108 (1955).

14 Newman, E. A, \& Feldman, M, Jr Massive Picrotoxin Therapy in Treatment of Acute Barbiturate Poisoning Arch. Int. Med 81 690-695 (May, 1948)

15 Eckenhoff, J. E, Schmmt, C F., Dripps, R. D, \& KetY, S. S A Status Report on Analeptics, Councll on Pharmacy and Chemistry J.A M A 139 780-785 (March 19, 1949).

16. Roche, M, Wynne, L. C, \& Hoskins, D M Therapy of Acute Barbiturate Poisoning Report of 3 Cases. Ann. Int. Med. 33: 73-82 (1950)

17. Cornell Conference on Therapy of Barbiturate Poisoning Am J Med 1. 93-103 (1946).

18. Arnett, J. H Ephedrne and Picrotoxin Used Successfully in Amytal Poisoning J A.M A. 100. 1593 (1933).

19 Quastel, J. H, \& Wheatley, A. H. M. Oxidation by the Bram Biochem J 26725 (1932)

20. Soskin, S, \& Taubenhaus, M Sodium Succinate as an Antidote for Barbiturate Poisoning, and in the Control of the Duration of Barbiturate Anaesthesia (mcluding Its Successfu. Use in a Case of Barbiturate Poisoning in a Human). J Pharmacol \& Exper Therap 78: 49-55 (1943).

21. Larson, E., Wynn, M F, \& Adams, J P Sodium Succinate in Pentobarbital Depression of Cerebral Cortex and Medulla Oblongata Anesthesiology 16:239 (March, 1955).

22 Lanson, E., Wrnn, M F, \& Adams, J P Studies of Pentobarbital Depression. Anesthesiology 15: 537 (Sept, 1954)

23 Giarman, N. J, Rowe, R P., \& Young, J F The Effect of Sodium Succinate and Some of Its Derivatives on Thiopental Anesthesia. Anesthesiology 15 122-125 (May, 1954).

24 Schack, J A, \& Goldbaum, L R. The Analeptic Effect of Sodium Succinate in Barbiturate Anaesthesia in Rabbits J Pharmacol. \& Exper Therap 96 $315-324$ (1949) 
25. BEYER, K. H., \& LATVEN, A R, An Evaluation of the Influence of Succinate and Malonate on Barbiturate Hypnosis. J. Pharmacol. \& Exper. Therap. 81.203 (1944).

26. Tucci, J. H., Brazier, M A. B., Mines, H. H. W., \& Finesinger, J E. A Study of Pentothal Sodum Anesthesia and a Critical Investigation of the Use of Succinate as an Antidote. Anesthesiology 10: 25-39 ( Jan, 1949)

27. Barretr, R. H. Sodum Succinate: An Analeptic for Barbiturate Poisoning in Man Ann Int. Med. 31: 739 (Nov., 1949).

28. Westralt, B. A. Pyruvic Acid Antagonism to Barbiturate Depression. J. Pharmacol \& Exper. Therap 8733 (May, 1946).

29. Shaw, F. H.; Simon, S E, Cass, N. M.; Shulman, A.; Anstré, J. R.; \& Nelson, E. R Nature (London) 174402 (1954).

30. Annotations: Treatment of Barbiturate Poisoning Brit. M.J. 2. 1076 (Oct. 29, 1955).

31 Marsirald, P. B., \& Vallance, D. K J Pharmacol. \& Exper. Therap 10: 740 (1954).

32 Cass, N. M. An Electro-Encephalographic Study of the Analeptc Action of B-B-ethyl methyl glutarimide (Megimide). I, Aganst Several Barbiturates and Other Hypnotics, II, Compared with Other Analeptics and Convulsants. Brit J. Anaesth 28. 324 (July, 1956).

33. Clemmesen, C. Effect of Megimide and Amiphenazole on Respiratory Paresis. Lancet 271 (6950): 966 (Nov. 10, 1956).

34. Penersen, J. Arousing Effect of Megimide and Amphenazole Lancet 271 (6950): 965 (Nov. 10, 1956).

35. LAUw, A, \& Sonne, L M. Megimide in the Treatment of Barbituric Acid Poisoning Lancet 271 (6950) 961 (Nov. 10, 1956).

36. Kjagr-Lansen, J. Delerious Psychosis and Convulsions due to Megimide. Lancet 271 (6950): 967 (Nov. 10, 1956).

37. RuchaRds, R. K., \& TaYLOR, J. D. In press, cited in (8)

38. Sunshine, I, \& Leonards, J. R. Use of the Artificial Kidney for Removal of Barbiturates in Dogs Proc Soc Exper. Biol. \& Med. 86: 638-641 (1954).

39. Kyle, L K., Jeghers, H, Walsh, W. P ; Doolan, P D, Wishinskx, H, \& Pallotta, A The Application of Hemodralysis to the Treatment of Barbiturate Poisoning $\mathrm{J}$ Clin. Investigation 32: 364-371 (1953).

40. Alwall, N., Lindgren, P, \& Winnerquist, A. Artficial Kidney. Treatment of Severe Phenobarbital Poisoning in Rabbits by Means of Forced Polyuria, Exchange Ultrafiltration, and Dialysis and Preluminary Report on Dialytic Treatment of Barbiturate Poisoning in Patients Acta med Scandinav. 147: 119-120 (1953).

41. Lackey, $\mathrm{R}$ W., BaIley, H. A, \& Goth, A. Use of Peritoneal Lavage in the Treatment of Experimental Pentobarbital Poisoning Texas Repits, on B1ol. \& Med 12. I (1954).

42 Pallotta, A, Bucher, G, Krle, L, \& Kappany, T. The Artificial Kidney as a Method in the Study of Drug Fixation and Poisoning (Abstract). J Pharmacol \& Exper Therap 106: 409 (1952).

43. Brown, I. A., Ansel , J. S., \& Schiele, B C. The Use of Hemodialysis in the Treatment of Barbiturate Intoxication. Minnesota Med. 37: 650-652 (1954).

44. Annotations: Hemodialysis for Barbiturate Poisoning Lancet 271 (10) 503 (Sept. 8, 1956).

45. RoвIE, T. R. Treatment of Acute Barbiturate Poisoning by Nonconvulsive Electrostimulaton. Post-Grad. Med. 9: 253 (March, 1951).

46. Blackly, P. H., \& Brookrart, J M Studies on Analeptic Action of Electrical Strmulation in Barbiturate Poisoning. Anesthesiology 16: 151 (March, 1955). 